\title{
ANALISIS PENGARUH FRAUD PENTAGON DALAM MENDETEKSI FRAUDULENT FINANCIAL REPORTING PADA PERUSAHAAN JASA NONKEUANGAN
}

\section{PERIODE 2015-2017}

\author{
Yuliamos Tirta Wijaya Pasaribu ${ }^{1}$ \\ Fakultas Ekonomi Bisnis Unika Atma Jaya, Indonesia \\ amostirtawp@gmail.com \\ Synthia Madya Kusumawati ${ }^{2}$ \\ Fakultas Ekonomi Bisnis Unika Atma Jaya, Indonesia \\ synthia.madya@atmajaya.ac.id \\ L. Jade Faliany ${ }^{3}$ \\ Fakultas Ekonomi Bisnis Unika Atma Jaya, Indonesia \\ jade.faliany@atmajaya.ac.id \\ Diterima 5 Mei 2020 \\ Disetujui 2 Juni 2020
}

Abstract-This research aimed at analyzing the effect of fraud pentagon proxied by nine variables, namely financial stability, personal financial needs, external pressure, financial targets, ineffective monitoring, industry characteristics, auditor changes, director changes, and frequent number of CEO's picture towards fraudulent financial reporting proxied by Beneish M-Score at non-financial service companies listed on the Indonesia Stock Exchange (IDX) period 2015-2017. The data used were secondary data obtained from annual reports and financial statements of nonfinancial service companies period 2015-2017 with a total of 285 eligible samples. The data analysis methods used were descriptive statistical analysis and logistic regression analysis. The results showed that the variables of financial stability and the nature of the industry generated a significant and positive effect on fraudulent financial reporting. Meanwhile, the variables of personal financial needs, external pressure, financial targets, ineffective monitoring, auditor changes, director changes, and often the CEO's image were not significant to fraudulent financial reporting.

Keywords: Fraud Pentagon, Fradulent Financial Reporting, Beneish M-Score 


\section{PENDAHULUAN}

Laporan Keuangan berisi informasi yang bermanfaat bagi para penggunanya. Menurut PSAK 1 (IAI, 2018) informasi dari laporan keuangan antara lain berupa informasi mengenai posisi keuangan, kinerja keuangan, arus kas entitas, yang merupakan hasil dari pertanggungjawaban manajemen perusahaan dalam menjalankan kegiatan operasional perusahaan selama satu periode. Laporan tersebut dapat digunakan oleh manajemen perusahaan untuk mengevaluasi, melakukan perencanaan, dan membuat keputusan. Laporan keuangan dibuat sebagai bentuk pertanggungjawaban manajemen kepada para emangku kepentingan perusahaan. Di samping itu, laporan keuangan juga berperan untuk menunjukkan kredibilitas perusahaan. Laporan keuangan yang baik dan transparan memberi arti bahwa perusahaan tersebut telah menjalankan kegiatan operasionalnya dengan baik.

Agency theory yang dikemukakan oleh Jensen dan Meckling (1976) menjelaskan bahwa terkadang dapat terjadi perbedaan kepentingan (conflict of interest) antara pemilik modal/perusahaan (prinsipal) dan manajer (agen). Manajer adalah agen yang diberi kepercayaan oleh prinsipal untuk memaksimalkan kepentingan mereka. Akan tetapi manajer juga berusaha untuk memaksimalkan kepentingannya sendiri. Perbedaan kepentingan antara agen dan prinsipal dapat berdampak pada kualitas laporan keuangan perusahaan. Adanya kepentingan manajer yang ingin memenuhi tuntutan prinsipal untuk memaksimalkan keuntungan dapat berdampak pada kualitas laporan keuangan perusahaan. Tuntutan prinsipal ini dapat menjadi pemicu bagi manajer untuk melakukan kecurangan atas laporan keuangan perusahaan.

Kasus laporan keuangan PT Garuda Indonesia Tbk menjadi bukti terjadinya conflict of interest. Pihak manajemen menyajikan laporan keuangan yang tidak sesuai dengan aturan, yang disebabkan oleh adanya tekanan dari dewan direksi. Seperti yang diberitakan di situs kompas 26 Juli 2019, kasus ini berawal dari laporan keuangan PT Garuda Indonesia Tbk tahun 2018. Laporan tersebut menyajikan laba bersih Perusahaan sebesar USD 809,85 ribu atau setara dengan Rp11,33 miliar (asumsi kurs Rp14.000 per dolar AS). Angka yang disajikan melonjak tajam dibanding tahun sebelumnya (2017) yang menunjukkan Perusahaan menderita kerugian sebesar USD 216,5 juta. Hal ini terjadi karena diakuinya piutang secara penuh pada tahun 2018, yang seharusnya diakui secara bertahap selama beberapa tahun ke depan. Kasus ini membuat PT Garuda Indonesia Tbk dikenai sanksi denda sebesar Rp250 juta oleh Bursa Efek Indonesia. Otoritas Jasa Keuangan (OJK) dan Kementerian Keuangan juga memberi sanksi denda kepada para anggota komisaris dan dewan direksi PT Garuda Indonesia Tbk sebesar Rp100 juta per orang. Kasus yang terjadi pada Badan Usaha Milik Negara (BUMN) ini sempat menjadi trending topic di Indonesia dan menimbulkan pertanyaan seberapa banyak kecurangan terhadap laporan keuangan yang telah terjadi.

Menurut SAS no.99 (2002), misstatements yang terjadi dalam kecurangan atas laporan keuangan dilakukan dengan sengaja untuk menipu pengguna laporan keuangan. Umumnya, kecurangan yang dilakukan memiliki tujuannya masing-masing, seperti memaksimalkan bonus bagi manajemen dengan menyajikan laporan keuangan yang overstatement, atau untuk menghindari pajak dengan menyajikan laporan keuangan yang understatement. Kecurangan atas laporan keuangan dapat dilakukan dengan berbagai cara, seperti melaporkan penghasilan fiktif, penilaian aset yang tidak tepat, dan pengungkapan laporan keuangan yang tidak tepat.

Berdasarkan hasil survei yang dilakukan oleh Association of Certified Fraud Examiners Indonesia Chapter atau ACFE Indonesia Chapter (2016), dari 154 responden jumlah fraud atas 
laporan keuangan mencapai $2 \%$. Jumlah kerugian fraud atas laporan keuangan sebesar 4\%. Sisa persentase jumlah fraud dan banyaknya persentase kerugian terjadi pada fraud korupsi dengan persentase terbesar dan diikuti oleh fraud penyalah- gunaan aset. Temuan ini berbeda dengan hasil survei ACFE global (2016) yang menyatakan bahwa fraud atas laporan keuangan merupakan fraud yang paling merugikan. Terjadinya perbedaan tersebut diduga karena di Indonesia fraud atas laporan keuangan belum banyak terungkap, seperti fraud tentang penipuan informasi pajak dan penipuan informasi di bursa efek.

Crowe's Fraud Pentagon adalah hasil pengembangan dari teori fraud triangle yang dikemukakan oleh Crowe Horwarth (2011). Crowe's fraud pentagon memberi gambaran tentang beberapa kondisi penyebab fraud (kecurangan) atas laporan keuangan, yaitu berupa pressure, opportunity, rationalization, capabillty, dan arrogance. Beberapa komponen pengukuran Pressure antara lain adalah financial targets, personal financial needs, external pressure, dan financial stability. Opportunity dapat diukur dengan ineffective monitoring dan nature of industry. Rationalization memiliki satu pengukuran, yaitu auditor change. Capability dapat diukur dengan director change dan Arrogance diukur dengan frequent number of CEO's picture. Kondisi-kondisi tersebut dapat dijadikan sebagai indikasi penyebab terjadinya kecurangan.

\section{LITERATUR REVIEW DAN PENGEMBANGAN HIPOTESIS}

Agency Theory menjelaskan bahwa hubungan antara principle dan agent dapat dikatakan efisien jika kedua belah pihak memiliki informasi yang sama dan tidak menutupi informasi yang dimiliki, sehingga antara satu pihak dengan pihak yang lainnya diuntungkan. Namun principle harus membayar agent sesuai dengan kontribusinya, karena berbagai informasi yang dimiliki oleh perusahaan sebagian besar berada ditangan agent. Penyebab timbulnya konflik keagenan karena para pengambil keputusan tidak perlu menanggung resiko sebagai akibat adanya kesalahan dalam pengambilan keputusan bisnis atau tidak dapat meningkatkan nilai perusahaan. Resiko tersebut sepenuuhnya ditanggung oleh para pemilik. Konflik kepentingan antara manajer dan pemegang saham dapat diminimalkan melalui cara: Manajer diberikan insentif atas tindakanya sesuan dengan kepentingan pemegang saham.

Berbagai penelitian mengenai kecurangan atas laporan keuangan telah banyak dilakukan sehubungan dengan teori yang digunakan untuk mendeteksi kecurangan atas laporan keuangan. Para peneliti menggunakan teori pendeteksian kecurangan seperti fraud triangle, fraud diamond, dan fraud pentagon. Elemen-elemen yang digunakan dalam teori pendeteksian kecurangan atas laporan keuangan tersebut antara lain pressure, opportunity, rationalization, capability/competence, dan arrogance.

Laila Tiffani., (2015) menganalisis pengaruh fraud triangle dalam menjelaskan fenomena kecurangan atas laporan keuangan. Penelitian ini menggunakan tujuh variabel independen. Empat variabel dari elemen pressure diproksikan dengan financial stability, personal financial needs, external pressure, dan financial targets. Dua variabel dari elemen opportunity diproksikan dengan nature of industry dan ineffective monitoring. Satu variabel dari elemen rationalization diproksikan dengan auditor change. Sampel penelitian ini terdiri dari 36 perusahaan yang melakukan fraud dan 54 perusahaan yang tidak melakukan fraud selama 2011 sampai dengan 2013. Hasil penelitian menunjukkan bahwa financial stability dan external pressure berpengaruh positif terhadap kecurangan atas laporan keuangan, sedangkan ineffective monitoring berpengaruh negatif terhadap kecurangan atas laporan keuangan. Personal financial needs, financial targets, 
nature of industry, dan auditor change tidak berpengaruh terhadap kecurangan atas laporan keuangan.

Fraud pentagon merupakan teori yang dikemukakan Horwarth (2011b) dalam mendeteksi terjadinya fraud. Teori ini dikemukakan pada tahun 2011 yang dinamakan The Crowe's Fraud Pentagon dengan menambahkan dua elemen penyebab fraud lainnya, yaitu kompetensi (competence) dan arogansi (arrogance). Fraud Pentagon ini merupakan penyempurnaan dari teori sebelumnya yakni Fraud diamond Theory (Wolfe \& Hermanson, 2004). Elemen kompetensi (competence) yang ada dalam teori fraud pentagon memiliki arti yang sama dengan kemampuan (capability) yang dijelaskan di dalam teori fraud diamond oleh (Wolfe \& Hermanson, 2004). Kompetensi atau kapabilitas merupakan kemampuan seseorang untuk memengaruhi pengendalian internal, mengembangkan strategi untuk bersembunyi dan mengontrol situasi sosial sehingga menguntungkan pribadinya (Horwarth, 2011b). Sementara elemen lainnya, arogansi (arrogance), diartikan sebagai suatu sikap yang menunjukkan bahwa pengendalian internal, kebijakan, dan peraturan perusahaan tidak berlaku bagi dirinya dan merasakan adanya keleluasaan untuk melakukan fraud tanpa ada rasa bersalah. Seseorang yang memiliki sikap arogan karena merasa dirinya memiliki superioritas atas hak yang dimilikinya (Horwarth, 2011b)

Aprilia (2017) melakukan penelitian mengenai prediksi kecurangan atas laporan keuangan dengan menggunakan teori fraud pentagon. Variabel yang digunakan untuk mengukur fraud pentagon adalah financial targets, financial stability, liquidity, institutional ownership, effective monitoring, external auditor quality, changes in auditor, director change, dan frequent number of CEO's picture. Populasi yang digunakan dalam penelitian ini adalah perusahaan manufaktur yang terdaftar di Bursa Efek Indonesia (BEI) dengan jumlah sampel sebanyak 46 perusahaan. Hasil penelitian menunjukkan bahwa tiga variabel yaitu financial stability, external auditor quality, dan frequent number of CEO's picture berpengaruh positif terhadap fraudulent financial reporting. Financial targets, liquidity, institutional ownership, effective monitoring, changes in auditor, dan director change tidak berpengaruh terhadap fraudulent financial reporting.

Penelitian tentang kecurangan atas laporan keuangan juga dilakukan oleh yaitu dengan menggunakan variabel financial targets, financial stability, external pressure, personal financial needs, ineffective monitoring, audit opinion, changes in auditor, dan capability to replace any directors. Penelitian ini menggunakan 105 sampel bank yang terdaftar yang terdaftar di BEI pada periode 2014 - 2016. Hasil penelitian menunjukkan bahwa financial stability, ineffective monitoring, nature of industry, audit opinion, dan changes in auditor tidak berpengaruh terhadap kecurangan atas laporan keuangan, sedangkan personal financial needs dan frequent number of CEO's picture berpengaruh positif terhadap kecurangan atas laporan keuangan.

Vivianita \& Indudewi (2018) melakukan penelitian tentang pengaruh fraud pentagon dalam mendeteksi kecurangan atas laporan keuangan pada perusahaan sektor pertambangan. Hasil penelitian menunjukkan bahwa variabel financial targets dan frequent number of CEO's picture memiliki pengaruh terhadap kecurangan atas laporan keuangan, sedangkan external pressure, auditor change, nature of industry, dan director change tidak memiliki pengaruh terhadap kecurangan atas laporan keuangan.

Nurbaiti \& Hanafi (2017) melakukan penelitian tentang fraud diamond dalam mendeteksi fraudulent financial statement. Hasil penelitian menunjukkan bahwa financial targets, ineffective monitoring, dan nature of industry berpengaruh terhadap fraudulent financial statement, 
sedangkan financial stability, external pressure, auditor change, dan director change tidak berpengaruh terhadap fraudulent financial statement.

Mardianto (2019) melakukan penelitian tentang pengaruh fraud triangle dalam mendeteksi kecurangan atas laporan keuangan. Hasil penelitian menunjukkan bahwa financial stability dan auditor change berpengaruh terhadap kecurangan atas laporan keuangan, sedangkan external pressure, ineffective monitoring, dan financial targets tidak berpengaruh terhadap kecurangan atas laporan keuangan.

Pamungkas (2018) melakukan penelitian tentang penggunaan fraud pentagon untuk menganalisis kecurangan atas laporan keuangan. Hasil penelitian menunjukkan bahwa variabel external pressure dan nature of industry berpengaruh terhadap kecurangan atas laporan keuangan, sedangkan variabel financial stability, ineffective monitoring, financial targets, dan director change tidak berpengaruh terhadap kecurangan atas laporan keuangan.

\subsection{Pengembangan Hipotesis}

1. Pengaruh Financial Stability terhadap Fraudulent Financial Statement

Perusahaan dapat dikatakan stabil apabila kondisi keuangan perusahaan dapat memenuhi semua kebutuhan kinerja operasional perusahaan baik yag sifatnya rutin ataupun mendadak. Jika hal sebaliknya kondisi keuangan tidak stabil maka perusahaan rentan mengalami financial distress dan ketidakmampuan perusahaan untuk memenuhi target Manager akan mendapatkan tekanan dari atasan jika keuangan perusahaan tidak stabil sehingga manajer cenderung untuk melakukan kecurangan salah satunya dengan melakukan manipulasi laporan keuangan di area pendapatan. Tiffani \& Marfuah (2015) membuktikan financial stability memberikan pengaruh pada fraudulent financial reporting. Financial Stability diproksikan dengan AGROW

\section{H1: Financial Stability Berpengaruh Untuk Mendeteksi Fraudulent Financial Statement.}

2. Pengaruh Personal Financial Needs terhadap Fraudulent Financial Statement

Personal Financial Need pada penelitian ini merujuk pada kebutuhan keuangan personal dari eksekutif perusahaan (dewan komisaris dan dewan direksi). Ketika para eksekutif perusahaan memiliki peranan yang signifikan di dalam perusahaan maka personal financial need dari para eksekutif tersebut akan dipengaruhi oleh kinerja keuangan perusahaan. Apabila kinerja keuangan perusahaan baik maka keadaan finansial personal para eksekutif yang mempunyai saham di perusahaan tersebut juga baik. Begitu sebaliknya, apabila kinerja keuangan perusahaan itu buruk maka keadaan finansial dari personal eksekutif perusahaan juga buruk. Dalam penelitian Skousen, Smith, \& Wright (2009) membuktikan bahwa semakin tinggi financial personal need yang diproksikan persentase kepemilikan saham yang dimiliki orang dalam maka probabilitas terjadinya fraud dalam laporan keuangan semakin rendah. Menurut Nugraheni \& Triatmoko (2017) personal financial need berpengaruh pada fraudulent financial reporting.

\section{H2 : Personal financial need berpengaruh terhadap fraudulent financial reporting}

3. Pengaruh External Pressure terhadap Fraudulent Financial Statement

External pressure adalah adanya tekanan dari pihak luar seperti kreditur dan investor. Hal ini akan memberikan sinyal negative ketika perusahaan tidak mampu memenuhi pembayaran kepada pihak kreditor ataupun memberikan tingkat keuntungan dari modal yang diberikan 
oleh investor. Tekanan yang berlebihan dapat mendorong para manager untuk melakukan fraud terutama dari pihak eksternal yaitu kreditor, ketidakmampuan perusahaan membayar hutangnya membuat perusahaan sulit untuk mendapatkan pendanaan berupa hutang, namun perusahaan wajib melunasi seluruh hutangnya kepada kreditor. Tiffani \& Marfuah (2015) menyatakan bahwa leverage (LEV) yang lebih besar dapat dikaitkan dengan kemungkinan yang lebih besar untuk melakukan pelanggaran terhadap perjanjian kredit dan kemampuan yang lebih rendah untuk memperoleh tambahan modal melalui pinjaman. External Pressure diproksikan dengan DER

\section{H3: External Pressure Berpengaruh Untuk Mendeteksi Fraudulent Financial Statement.}

4. Pengaruh Financial Target terhadap Fraudulent Financial Statement

Perusahaan dapat dikatakan memenuhi target perusahaan apabila dapat menghasilkan produk secara maksimal dengan asset yang dimilikinya sehingga return yang didapat perusahaan menjadi semakin membaik. Hal ini memberikan sinyal positif dari pihak kreditor dan investor bahwa perusahaan mampu menghasilkan laba dengan menggunakan asset yang dimilikinya . Jika hal sebaliknya target perusahaan tidak tercapai, agen cenderung untuk memanipulasi laporan keuangannya untuk mendapatkan bonus atas kinerja mereka dengan memanipulasi laba perusahaan. Semakin tinggi kemampuan perusahaan untuk mencapai target finansialnya dapat dikatakan bahwa kinerja perusahaan semakin baik. Namun terkadang ada faktor-faktor tertentu yang tidak dapat dikendalikan perusahaan sehingga membuat target finansial tersebut tidak tercapai dan eksistensi perusahaan akan diragukan. Nugraheni \& Triatmoko (2017) meneliti variabel yang dapat digunakan untuk proksi ukuran dari komponen tekanan dan peluang berdasarkan teori fraud diamond yang diadopsi dalam SAS (No.99) dengan menggunakan analisis regresi logistik. Berdasarkan hasil analisis, maka dapat diambil kesimpulan bahwa variabel financial target dengan proksi return on asset (ROA) terbukti berpengaruh secara signifikan terhadap kemungkinan adanya kecurangan pada laporan keuangan. Penelitian serupa juga dilakukan oleh Vivianita \& Indudewi (2018) yang menunjukan variabel financial target memiliki pengaruh pada fraudulent financial reporting. Financial Target diproksikan dengan ROA

\section{H4: Financial Target Berpengaruh Untuk Mendeteksi Fraudulent Financial Statement.}

5. Pengaruh Ineffective Monitoring terhadap Fraudulent Financial Statement

Perusahaan dengan pemegang saham dari Direksi dan atau Komisaris lebih memiliki kemungkinan untuk menghindari tindak kecurangan, dengan attitude toward money yang dimiliki mereka akan berupaya untuk memastikan bahwa tidak akan ada tindakan yang dapat berdampak buruk pada kondisi finansial perusahaan, yang juga akan mempengaruhi kondisi finansial mereka. Dewan komisaris independen dipercaya dapat memberikan pengawasan yang lebih baik karena bersifat independen dan tidak dapat dipengaruhi dari berbagai pelaku fraud. Nurbaiti \& Hanafi (2017) menunjukan bahwa ineffective monitoring berpengaruh terhadap fraudulent financial reporting. Ineffective Monitoring diproksikan dengan jumlah komisaris independen.

\section{H5: Ineffective Monitoring Berpengaruh Untuk Mendeteksi Fraudulent Financial Statement.}


6. Pengaruh Nature of industry terhadap Fraudulent Financial Statement

Pada laporan keuangan terdapat akun-akun yang besaran saldonya ditentukan oleh perusahaan itu sendiri melalui suatu estimasi, misalnya estimasi saldo piutang yang tidak tertagih. Karena adanya penilaian subjektif dalam menentukan saldo dari akun tersebut, manajemen dapat menggunakan akun tersebut sebagai alat untuk manipulasi laporan keuangan. Argumen ini didukung oleh Skousen, Smith, \& Wright (2009) yang menemukan bahwa akun piutang dan persediaan terlibat dalam sejumlah besar fraud. Estimasi nilai piutang dapat dihitung besaran nilainya, perusahaan dapat menggunakan akun tersebut untuk memanipulasi laporan keuangan dengan cara melebihkan saldo penyisihan piutang tak tertagih agar dapat mengurangi laba. Hal tersebut dilakukan untuk menciptakan cadangan laba yang dapat digunakan untuk menaikkan laba di kemudian hari saat perusahaan tidak dapat mencapai target. Oleh karena itu, nature of industry dalam penelitian ini diproksikan dengan rasio perubahan piutang penjualan selama dua tahun. Semakin tinggi rasio perubahan piutang yang merupakan proksi dari nature of industry, kemungkinan terjadinya kecurangan juga tinggi. Menurut penelitian yang dilakukan oleh (Pamungkas, 2018) nature of industry memengaruhi fraudulent financial reporting.

H6: Nature of industry berpengaruh Untuk Mendeteksi Fraudulent Financial Statement.

7. Pengaruh auditor change terhadap Fraudulent Financial Statement

Pergantian auditor oleh perusahaan dapat diasumsikan sebagai cara untuk menghapus jejak kecurangan yang telah dilakukan komite audit sebelumnya. Kemungkinan tersebut mendorong niat perusahaan merubah susunan komite auditnya demi menutupi kecurangan yang telah dilakukan oleh perusahaan.

Hasil dalam penelitian yang telah dilakukan oleh Mardianto (2019) Penelitian tersebut menunjukkan hasil bahwa ada dua faktor yang memiliki pengaruh signifikan terhadap kecurangan pelaporan keuangan salah satunya yaitu pergantian auditor. Pergantian auditor yang terlalu sering dilakukan memberi pikiran bawah kemungkinan perusahaan tersebut melakukan manipulasi laba yang disajikan, sehingga pergantian auditor dapat bertujuan agar tindakan kecurangan tersebut tidak dapat diketahui oleh auditor pengganti.

\section{H7: Auditor Change Berpengaruh Untuk Mendeteksi Fraudulent Financial Statement.}

8. Pengaruh Director Change terhadap Fraudulent Financial Statement

Wolfe \& Hermanson (2004) berpendapat bahwa suatu tindakan kecurangan pelaporan keuangan tidak mungkin terjadi tanpa adanya seseorang yang memiliki kemampuan dalam perusahaan. Direksi merupakan seseorang yang berpengaruh dalam suatu perusahaan. Seluruh kebijakan perusahaan dibuat oleh pihak direksi. Umumnya, perusahaan melakukan pergantian direksi atau perubahan susunan direksi atau pemilihan direksi baru sebagai upaya untuk memperbaiki kinerja direksi lama yang dianggap kurang kompeten. Namun, pergantian direksi dapat dianggap sebagai salah satu cara untuk menyingkirkan pihak direksi lama yang mengetahui adanya indikasi terjadinya praktik kecurangan dalam suatu perusahaan.

Hasil penelitian yang dilakukan oleh Septriani \& Handayani (2018) menunjukkan bahwa director change berpengaruh terhadap fraudulent financial reporting.

H8: Director Change Berpengaruh Untuk Mendeteksi Fraudulent Financial Statement. 
9. Pengaruh Arrogance terhadap Fraudulent Financial Statement

Studi yang dilakukan oleh Committee of Sponsoring Organization of the Threadway Comission (COSO) menemukan bahwa $70 \%$ dari fraud memiliki profil yang menggabungkan tekanan dengan arogansi dan dari kasus penipuan 89\% CEO terlibat didalamnya. Crowe menunjukan bahwa terdapat lima unsur arogansi dari sudut pandang CEO, yaitu ego besar, menganggap mereka dapat menghindari kontrol internal, memiliki sifat menggertak, memiliki gaya manajemen okratis, dan takut kehilangan jabatan. Unsur arogansi tersebut dapat berkembang dan seiring waktu akan menghancurkan karir atau perusahaan. Teori tersebut didukung oleh penelitian Vivianita \& Indudewi (2018) menyatakan bahwa banyaknya foto CEO yang terpampang pada laporan tahunan perusahaan dapat mendemonstrasikan tingkat arogansi atau superioritas yang dimiliki CEO tersebut.

H9: Arrogance Berpengaruh Untuk Mendeteksi Fraudulent Financial Statement

\subsection{Model Penelitian}

Variabel Independen

Variabel Dependen

\begin{tabular}{|c|}
\hline \multicolumn{2}{|c|}{ Pressure (Tekanan) } \\
\hline Financial Stability $\quad(H 1)$ \\
\hline Personal Financial Need $(\mathrm{H} 2)$ \\
\hline External Pressure \\
\hline Financial Target \\
\hline
\end{tabular}

\begin{tabular}{|c|}
\hline Opportunity (Kesempatan) \\
\hline Ineffective Monitoring (H5) \\
\hline Nature of Industry $\quad(\mathrm{H} 6)$ \\
\hline
\end{tabular}
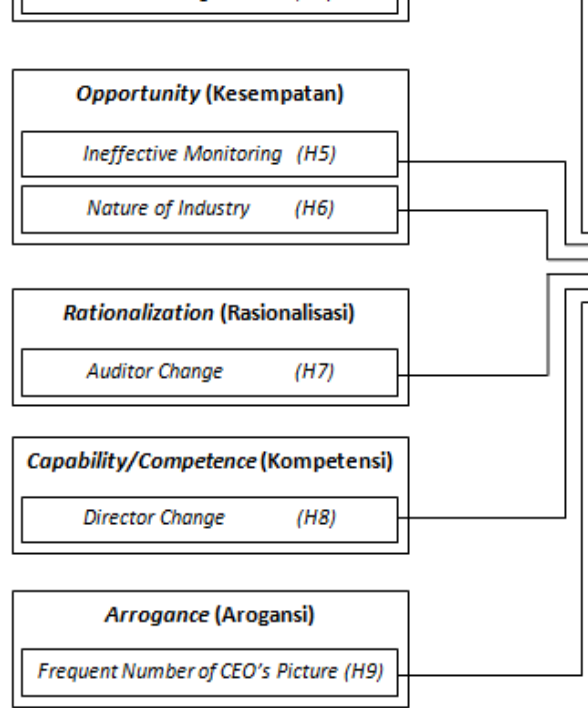


\section{METODOLOGI PENELITIAN DAN ANALISA DATA \\ 3.1 Populasi dan Sampel}

Populasi dari penelitian ini adalah seluruh perusahaan jasa nonkeuangan yang berjumlah 200 perusahaan dan tercatat di Bursa Efek Indonesia (BEI) pada periode 2015-2017. Pengambilan sampel penelitian menggunakan metode purposive sampling dan jumlah sampel yang diperoleh sebanyak 95 perusahaan per tahun.

Penelitian ini menggunakan data sekunder berupa laporan keuangan tahunan perusahaan yang tercatat yang terdaftar di BEI. Beberapa alasan menggunakan data sekunder adalah laporan keuangan perusahaan yang tercatat yang terdaftar di BEI lebih mudah diperoleh; penggunaan data sekunder sudah lazim digunakan oleh peneliti dalam negeri maupun luar negeri; dan laporan keuangan yang terdaftar di BEI dapat dipercaya karena telah diaudit oleh auditor independen. Variabel dependen yang digunakan dalam penelitian ini adalah fraudulent financial reporting (kecurangan atas laporan keuangan) yang diukur dengan menggunakan model Beneish M-Score (1999) (Beneish D. , 1999). Pengukuran Beneish M-Score (Beneish D. , 1999) menggunakan delapan rasio keuangan untuk mengidentifikasi apakah perusahaan terindikasi melakukan manipulasi pendapatan dalam laporan keuangannya, dengan rumus sebagai berikut:

$$
\begin{aligned}
M-\text { Score } & =-4.84+0.920 \mathrm{DSRI}+0.528 \mathrm{GMI}+0.404 \mathrm{AQI}+0.892 \mathrm{SGI} \\
& +0.115 \mathrm{DEPI}-0.172 \mathrm{SGAI}-0.327 \mathrm{LVGI}+4.697 \mathrm{TATA}
\end{aligned}
$$

\begin{tabular}{|c|c|c|c|}
\hline No & Rasio Keuangan & & Rumus \\
\hline \multirow{2}{*}{1} & \multirow{2}{*}{$\begin{array}{l}\text { Days Sales in Receivable Index } \\
\text { (DSRI) }\end{array}$} & \multirow{2}{*}{$D S R I=$} & (Net Receivables $t$ / Sales $t$ ) \\
\hline & & & (Net Receivables $t-1$ / Sales $t-1$ ) \\
\hline \multirow{2}{*}{2} & \multirow{2}{*}{ Gross Margin Index (GMI) } & \multirow{2}{*}{$G M I=$} & [(Sales $t-1$ - COGS $t-1) /$ Sales $t-1]$ \\
\hline & & & {$[($ sales $t-\operatorname{COGS} t) /$ Sales $t]$} \\
\hline \multirow{2}{*}{3} & \multirow{2}{*}{ Asset Quality Index (AQI) } & \multirow{2}{*}{$A Q I=$} & $(T A t-(C A t+P P E t) / T A t)$ \\
\hline & & & $(T A t-1-(C A t-1+P P E t-1) / T A t-1]$ \\
\hline \multirow{2}{*}{4} & \multirow{2}{*}{ Sales Growth Index (SGI) } & \multirow{2}{*}{$S G I=$} & Sales $t$ \\
\hline & & & Sales $t-1$ \\
\hline \multirow{2}{*}{5} & \multirow{2}{*}{ Depreciation Index (DEPI) } & \multirow{2}{*}{$D E P I=$} & [(Depreciation $t-1 /(P P E t-1+$ Depreciation $t-1)]$ \\
\hline & & & {$[($ Depreciation $t /(P P E t+$ Depreciation $t)]$} \\
\hline \multirow{2}{*}{6} & \multirow{2}{*}{$\begin{array}{l}\text { Sales General and } \\
\text { Administrative Expenses (SGAI) }\end{array}$} & \multirow{2}{*}{$S G A I=$} & (SG\&A Expense $t$ / Sales $t)$ \\
\hline & & & (SG\&A Expense $t-1$ / Sales $t-1)$ \\
\hline \multirow{2}{*}{7} & \multirow{2}{*}{ Leverage Index (LVGI) } & \multirow{2}{*}{$L V G I=$} & {$[(C L t+L T D t) / T A t]$} \\
\hline & & & {$[(C L t-1+L T D t-1) / T A t-1]$} \\
\hline \multirow{2}{*}{8} & \multirow{2}{*}{$\begin{array}{l}\text { Total Accruals to Total Assets } \\
\text { (TATA) }\end{array}$} & \multirow{2}{*}{ TATA $=$} & (Net Income From Continuing Operations t-Cash Flow From Operations t) \\
\hline & & & Total Assets \\
\hline
\end{tabular}

Tabel 3.1 Rasio Keuangan - Pengukuran Model Beneish

Sumber: Beneish 1999.

Perusahaan yang mendapatkan skor $>-2,22$ dikategorikan melakukan fraud, sedangkan perusahaan yang mendapat skor $\leq-2,22$ dikategorikan tidak melakukan fraud. Selanjutnya perusahaan yang melakukan fraud diberi kode 1 dan yang tidak melakukan fraud diberi kode 0 .

Variabel independen pertama adalah Financial stability, yaitu kondisi stabilitas keuangan perusahaan. Financial stability dihitung dengan rumus perubahan aset (ACHANGE).

$$
\text { ACHANGE }=\frac{\text { Total Asset } t-\text { Total Asset t }-1}{\text { Total Aset } t}
$$


Variabel independen kedua adalah personal financial needs, yaitu kondisi keuangan perusahaan yang dipengaruhi oleh kondisi kepemilikan oleh para eksekutif. Semakin tinggi persentase kepemilikan saham oleh orang dalam, maka kemungkinan praktik untuk memanipulasi laporan keuangan akan semakin tinggi terjadi.

\section{OSHIP $=\frac{\text { Total saham yang dimiliki orang dalam }}{\text { Total saham beredar }}$}

Variabel independen ketiga adalah external pressure yaitu tekanan berlebih yang dialami oleh manajer untuk memenuhi kewajiban kepada pihak ketiga. Agar perusahaan tetap mampu bersaing, perusahaan membutuhkan tambahan sumber modal dari luar (eksternal). Oleh karena itu leverage digunakan sebagai pengukuran variabel external pressure.

$$
\text { LEV }=\frac{\text { Total Debt }}{\text { Total Asset }}
$$

Variabel independen keempat adalah financial targets yaitu laba bersih yang akan dicapai atau ditargetkan. Manajer akan berusaha mewujudkan target yang telah ditentukan untuk mendapatkan imbalan berupa bonus atau hadiah. Return on asset (ROA) dapat digunakan untuk melihat seberapa efisien sebuah perusahaan menggunakan asetnya untuk menghasilkan laba bersih. Semakin tinggi ROA perusahaan, semakin baik kinerja manajemen.

$$
\text { ROA }=\frac{\text { Net income }}{\text { Total Asset }}
$$

Variabel independen kelima adalah ineffective monitoring yaitu suatu kondisi lemah atau tidak efektifnya pengawasan dalam memantau kinerja perusahaan. Menurut SAS no. 99, jumlah komisaris independen yang sedikit akan berdampak pada kurangnya pengawasan yang baik. Hal ini dapat menyebabkan munculnya pihak yang mendominasi manajemen perusahaan. Kondisi ini dapat mendorong terjadinya kecurangan atas laporan keuangan. Dalam penelitian ini, ineffective monitoring dihitung dengan membandingkan antara jumlah dewan komisaris independen dan total dewan komisaris.

\section{BDOUT $=\frac{\text { Jumlah dewan komisaris independen }}{\text { Jumlah total dewan komisaris }}$}

Variabel independen keenam adalah Nature of industry, yaitu kondisi ideal sebuah perusahaan dalam suatu industri. Rasio piutang usaha terhadap penjualan dapat digunakan sebagai pengukuran nature of industry. Dalam memperkirakan piutang usaha tak tertagih dibutuhkan penilaian subjektif. Dengan adanya penilaian subjektif dalam memperkirakan piutang usaha tak tertagih, hal ini dapat menjadi peluang bagi manajamen untuk melakukan kecurangan atas laporan keuangan dengan menggunakan akun tersebut.

\section{$R E C=\frac{\text { Receivables } t}{\text { Sales } t}-\frac{\text { Receivabels } t-1}{\text { Sales } t-1}$}

Variabel independen ketujuh adalah auditor change. Variabel ini dapat mengindikasikan perusahaan melakukan penghapusan jejak fraud (fraud trail) yang pernah dilakukan sebelumnya. Dalam penelitian ini auditor change (pergantian kantor akuntan publik) diukur dengan variabel dummy. Perusahaan yang melakukan pergantian auditor pada periode 2015-2017 diberi kode 1, sedangkan perusahaan yang tidak melakukan pergantian auditor pada periode 2015-2017 diberi kode 0 . 
Variabel independen kedelapan adalah director change. Pergantian direksi dapat dilakukan dengan alasan bahwa pergantian ini akan menjadikan direksi menjadi lebih kompeten. Dalam penelitian ini, untuk mengukur director change digunakan variabel dummy. Kode 1 diberikan apabila perusahaan melakukan pergantian direksi pada periode 2015-2017, sedangkan kode 0 diberikan apabila perusahaan tidak melakukan pergantian direksi pada periode 2015-2017.

Variabel independen kesembilan adalah frequent number of CEO's picture. CEO yang memiliki sifat arogansi tinggi dapat mengarah pada tindakan fraud, karena ia merasa dirinya tidak terikat pada peraturan dan regulasi sehingga dapat melakukan tindakan apapun untuk menguntungkan dirinya. Dalam penelitian ini, frekuensi kemunculan foto CEO dalam laporan tahunan digunakan untuk menghitung frequent number of CEO's picture.

\section{HASIL PENELITIAN DAN DISKUSI}

\subsection{Gambaran Umum Data Penelitian}

Gambaran umum sampel yang menjadi objek penelitian dapat dilihat dalam Tabel 4.1. Terdapat 200 perusahaan jasa nonkeuangan yang tercatat di Bursa Efek Indonesia (BEI) setiap tahunnya dan hanya 98 perusahaan yang memiliki data sesuai dengan tujuan penelitian.

Tabel 4.1 Tabel Seleksi Sampel Penelitian

\begin{tabular}{|c|l|c|}
\hline No. & Keterangan & Jumlah Perusahaan \\
\hline 1 & Perusahaan jasa non keuangan & 200 \\
\hline 2 & $\begin{array}{l}\text { Perusahaan yang tidak menerbitkan laporan tahunan } \\
\text { secara lengkap selama 2015-2017 }\end{array}$ & $(66)$ \\
\hline 3 & $\begin{array}{l}\text { Laporan keuangan disajikan dalam mata uang selain } \\
\text { Rupiah }\end{array}$ & $(12)$ \\
\hline 4 & $\begin{array}{l}\text { Perusahaan yang tidak memiliki data lengkap untuk } \\
\text { digunakan dalam penelitian }\end{array}$ & $(24)$ \\
\hline Jumlah sampel perusahaan & 98 \\
\hline Dikali 3 tahun laporan keuangan & x 3 \\
\hline Jumlah sampel tahun perusahaan (Firm years) & 294 \\
\hline $\begin{array}{l}\text { Sampel tahun perusahaan (Firm years) yang dikeluarkan karena } \\
\text { tidak memenuhi kriteria }\end{array}$ & $\mathbf{2 8 5}$ \\
\hline Jumlah sampel tahun perusahaan (Firm years) yang diteliti & $\mathbf{2 8 5}$ \\
\hline
\end{tabular}

Sumber : Data diolah peneliti 
Tabel 4.2 Tabel Klasifikasi Sampel Berdasarkan Sektor Industri

\begin{tabular}{|c|l|c|c|}
\hline No. & \multicolumn{1}{|c|}{ Sektor Industri } & Jumlah & Persentase \\
\hline 1 & Infrastruktur, utilitas, dan transportasi & 36 & 13 \\
\hline 2 & Properti, real estate, dan konstruksi bangunan & 122 & 43 \\
\hline 3 & Perdagangan, jasa, dan investasi & 127 & 45 \\
\hline & Total & $\mathbf{2 8 5}$ & $\mathbf{1 0 0}$ \\
\hline
\end{tabular}

Sumber : Data diolah peneliti

Berdasarkan tabel 4.2, dapat dilihat bahwa sektor perusahaan terbanyak berasal dari sektor perdagangan, jasa, dan investasi dengan jumlah sampel sebanyak 127 atau 45\%, sedangkan sektor paling sedikit adalah sektor infrastruktur, utilitas, dan transportasi dengan jumlah sampel sebanyak 36 atau $13 \%$.

\subsection{Analisis data}

Analisis statistika deskriptif dilakukan untuk menguji hipotesis yang telah dikembangkan. Pengujian hipotesis satu sampai dengan hipotesis sembilan dilakukan dengan menggunakan regresi logistik. Analisis regresi logistik digunakan karena variabel dependen merupakan nonmetrik dua kategori (variabel dummy) dan variabel independen merupakan kombinasi antara metrik dan non-metrik. Data yang telah dikumpulkan, ditabulasikan ke dalam tabel. Pengolahan data dan pengujian hipotesis dilakukan dengan menggunakan program Statistical Package for Social Science (SPSS) versi 25.0. Model regresi logistik yang digunakan untuk menguji hipotesis adalah:

$$
\begin{gathered}
F F R=\boldsymbol{k}+\beta_{1} A C H A N G E+\beta_{2} O S H I P+\beta_{3} L E V+\beta_{4} R O A+\beta_{5} B D O U T+\beta_{6} R E C \\
+\beta_{7} A U D C H A N G E+\beta_{8} D I C H A N G E+\beta_{9} C E O P I C+\varepsilon
\end{gathered}
$$

$\begin{array}{ll}\text { FFR } & =\text { variabel dummy, kode } 1 \text { melakukan fraud, kode } 0 \text { tidak melakukan fraud } \\ \boldsymbol{k} & =\text { konstanta } \\ \beta & =\text { Koefisien regresi } \\ \varepsilon & =\text { error } \\ \text { ACHANGE } & =\text { financial stability } \\ \text { OSHIP } & =\text { personal financial needs } \\ \text { LEV } & =\text { external pressure } \\ \text { ROA } & =\text { financial targets } \\ \text { BDOUT } & =\text { ineffective monitoring } \\ \text { REC } & =\text { nature of industry } \\ \text { AUDCHANGE } \quad=\text { auditor change } \\ \text { DICHANGE } & =\text { director change } \\ \text { CEOPIC } & =\text { frequent number of CEO's picture }\end{array}$ 
Tabel 4.3 Tabel Frekuensi

\section{FRAUD}

\begin{tabular}{ccc|c} 
& & Frequency & Percent \\
\hline Valid & FFR & 161 & 56.5 \\
\cline { 2 - 4 } & NON FFR & 124 & 43.5 \\
\cline { 2 - 4 } & Total & 285 & 100.0 \\
\hline
\end{tabular}

AUDCHANGE

\begin{tabular}{ccc|c} 
& & Frequency & Percent \\
\hline Valid & 0 & 196 & 68.8 \\
\cline { 2 - 4 } & 1 & 89 & 31.2 \\
\cline { 2 - 4 } & Total & 285 & 100.0 \\
\hline
\end{tabular}

\section{DICHANGE}

\begin{tabular}{ccc|c} 
& & Frequency & Percent \\
\hline Valid & 0 & 148 & 51.9 \\
\cline { 2 - 4 } & 1 & 137 & 48.1 \\
\cline { 2 - 4 } & Total & 285 & 100.0 \\
\hline
\end{tabular}

Sumber: Hasil olahan SPSS 25.0

Berdasarkan tabel 4.3, pada frekuensi FRAUD menunjukkan indikator NON FFR yang berarti bahwa sampel melakukan kecurangan pelaporan keuangan dan FFR menunjukkan adanya kecurangan pelaporan keuangan. Dari jumlah 285 sampel yang diolah, 161 di antaranya tidak melakukan kecurangan pelaporan keuangan. Hal ini menunjukkan bahwa mayoritas dari sampel tidak melakukan kecurangan pelaporan keuangan dengan persentase sebesar $56.5 \%$.

Angka 0 pada frekuensi AUDCHANGE menunjukkan perusahaan tidak melakukan pergantian auditor dan angka 1 menunjukkan perusahaan melakukan pergantian auditor. Dari jumlah 285 sampel yang diolah, 196 di antaranya tidak melakukan melakukan pergantian auditor. Hal ini menunjukkan bahwa mayoritas dari sampel tidak melakukan pergantian auditor dengan persentase sebesar $68.8 \%$.

Angka 0 pada frekuensi DICHANGE menunjukkan perusahaan tidak melakukan perubahaan dewan direksi dan angka 1 menunjukkan perusahaan melakukan perubahan dewan direksi. Dari jumlah 285 sampel yang diolah, 148 di antaranya tidak melakukan melakukan perubahaan dewan direksi. Hal ini menunjukkan bahwa mayoritas dari sampel tidak melakukan perubahaan dewan direksi dengan persentase sebesar 51,9\%. 
Tabel 4.4 X Overall Model Fit Test

Block 0: Beginning Block

Iteration History ${ }^{\mathrm{a}, \mathrm{b}, \mathrm{c}}$

\begin{tabular}{ccc|c} 
& & & Coefficient \\
\multicolumn{2}{c}{ Iteration } & likelihood & $\begin{array}{c}\mathrm{s} \\
\text { Constant }\end{array}$ \\
\hline Step 0 & 1 & 390.277 & -.260 \\
\cline { 2 - 4 } & 2 & 390.277 & -.261 \\
\cline { 2 - 4 } & 3 & 390.277 & -.261 \\
\hline
\end{tabular}

a. Constant is included in the model.

b. Initial -2 Log Likelihood: 390.277

c. Estimation terminated at iteration

number 3 because parameter estimates

changed by less than .001 .

Block 1: Method = Enter

Iteration History ${ }^{\mathrm{a}, \mathrm{b}, \mathrm{c}, \mathrm{d}}$

\begin{tabular}{|c|c|c|c|c|c|c|c|c|c|c|c|c|}
\hline \multirow[b]{2}{*}{ Iteration } & & \multirow{2}{*}{$\begin{array}{c}-2 \text { Log } \\
\text { likelihood }\end{array}$} & \multicolumn{10}{|c|}{ Coefficients } \\
\hline & & & Constant & ACHANGE & OSHIP & LEV & ROA & BDOUT & REC & AUDCHANGE & DICHANGE & CEOPIC \\
\hline \multirow[t]{5}{*}{ Step 1} & 1 & 327.693 & -.274 & 4.130 & -.162 & -.052 & .759 & -.494 & 3.773 & -.133 & .053 & -.032 \\
\hline & 2 & 317.113 & -.354 & 5.601 & -.202 & -.127 & 1.129 & -.606 & 7.565 & -.242 & .051 & -.038 \\
\hline & 3 & 315.993 & -.384 & 6.167 & -.226 & -.167 & 1.277 & -.654 & 9.402 & -.276 & .068 & -.039 \\
\hline & 4 & 315.980 & -.388 & 6.233 & -.228 & -.173 & 1.298 & -.660 & 9.632 & -.279 & .071 & -.040 \\
\hline & 5 & 315.980 & -.388 & 6.234 & -.228 & -.173 & 1.299 & -.660 & 9.635 & -.279 & .071 & -.040 \\
\hline \multicolumn{13}{|c|}{ b. Constant is included in the model. } \\
\hline \multicolumn{13}{|c|}{ c. Initial -2 Log Likelihood: 390.277} \\
\hline
\end{tabular}

\section{Sumber: Hasil olahan SPSS 25.0}

Tabel 4.4 menunjukkan bahwa nilai -LL awal sebesar 390,277. Nilai tersebut menunjukkan adanya penurunan nilai -2LL dan dapat disimpulkan bahwa model yang dihipotesiskan sesuai dengan data.

Tabel 4.5 Goodness of Fit Test

\section{Hosmer and Lemeshow Test}

\begin{tabular}{cc|c|c} 
Step & Chi-square & df & Sig. \\
\hline 1 & $\mathbf{1 3 . 6 6 8}$ & $\mathbf{8}$ & $\mathbf{. 0 9 1}$ \\
\hline
\end{tabular}

Sumber : Hasil olahan SPSS 25.0

Tabel 4.5 menunjukkan angka Chi-Square sebesar 13.668 dengan tingkat kebebasan (degree of freedom) sebesar 8. Nilai signifikansi yang diperoleh adalah 0,091 lebih besar dari nilai signifikansi yang telah ditetapkan yaitu $0,05 . \mathrm{H}_{0}$ diterima dan $\mathrm{H}_{\mathrm{a}}$ ditolak sehingga dapat disimpulkan bahwa tidak ada perbedaan antara model dan data. 
Tabel 4.6 Uji Koefisien Determinasi (Nagelkerke R-Square)

Model Summary

\begin{tabular}{cc|c|c} 
Step & $\begin{array}{c}-2 \text { Log } \\
\text { likelihood }\end{array}$ & $\begin{array}{c}\text { Cox \& Snell } \\
\text { R Square }\end{array}$ & $\begin{array}{c}\text { Nagelkerke R } \\
\text { Square }\end{array}$ \\
\hline 1 & $\mathbf{3 1 5 . 9 8 0}^{\mathbf{a}}$ & $\mathbf{. 2 2 9}$ & $\mathbf{. 3 0 8}$ \\
\hline
\end{tabular}

a. Estimation terminated at iteration number 6 because parameter estimates changed by less than .001 .

Sumber: Hasil olahan SPSS 25.0

Tabel 4.7 Pengujian Simultan

Omnibus Tests of Model Coefficients

\begin{tabular}{cc|c|c|c} 
& & Chi-square & df & Sig. \\
\hline \multirow{2}{*}{ Step 1 } & Step & $\mathbf{7 4 . 2 9 7}$ & $\mathbf{9}$ & $\mathbf{. 0 0 0}$ \\
\cline { 2 - 5 } & Block & $\mathbf{7 4 . 2 9 7}$ & $\mathbf{9}$ & $\mathbf{. 0 0 0}$ \\
\cline { 2 - 5 } & Model & $\mathbf{7 4 . 2 9 7}$ & $\mathbf{9}$ & $\mathbf{. 0 0 0}$ \\
\hline \multicolumn{3}{l}{ Sumber: Hasil olahan SPSS 25.0 }
\end{tabular}

Hasil pengolahan data menunjukkan nilai signifikansi sebesar 0. Nilai ini lebih kecil dari nilai signifikansi yang ditetapkan, yaitu 0,05 . Hal ini menunjukkan bahwa variabel independen secara bersama-sama dapat menjelaskan probabilita kecurangan atas laporan keuangan.

Angka Nagelkerke R Square pada tabel 4.6 adalah sebesar 0,308. Angka ini menunjukkan bahwa variabel dependen dapat dijelaskan oleh variabilitas variabel independen sebesar 0,308 atau $30,8 \%$. Sisanya sebesar 69,2\% dijelaskan oleh variabel di luar model penelitian.

Tabel 4.8 Pengujian Hipotesis

Variables in the Equation

\begin{tabular}{|c|c|c|c|c|c|c|c|}
\hline & & & S.E. & Wald & $\mathrm{df}$ & Sig. & $\operatorname{Exp}(B)$ \\
\hline \multirow[t]{8}{*}{ Step $1^{\mathrm{a}}$} & ACHANGE & 6.234 & 1.304 & 22.838 & 1 & .000 & 509.801 \\
\hline & OSHIP & -.228 & .957 & .057 & $\mathbf{1}$ & .812 & .796 \\
\hline & LEV & -.173 & .475 & .132 & 1 & .716 & .841 \\
\hline & ROA & 1.299 & 2.061 & .397 & $\mathbf{1}$ & .529 & 3.665 \\
\hline & BDOUT & -.660 & 1.199 & .303 & 1 & .582 & .517 \\
\hline & REC & 9.635 & 2.188 & 19.391 & $\mathbf{1}$ & .000 & 15293.071 \\
\hline & $\begin{array}{l}\text { AUDCHAN } \\
\text { GE }\end{array}$ & -.279 & .312 & .798 & 1 & .372 & .757 \\
\hline & DICHANGE & .071 & .281 & .063 & 1 & .802 & 1.073 \\
\hline
\end{tabular}




\begin{tabular}{l|l|l|l|l|l|l|l|}
\hline CEOPIC & $\mathbf{- . 0 4 0}$ & $\mathbf{. 0 5 0}$ & $\mathbf{. 6 1 7}$ & $\mathbf{1}$ & $\mathbf{. 4 3 2}$ & $\mathbf{. 9 6 1}$ \\
\hline Constant & $\mathbf{- . 3 8 8}$ & $\mathbf{. 6 3 5}$ & $\mathbf{. 3 7 4}$ & $\mathbf{1}$ & $\mathbf{. 5 4 1}$ & $\mathbf{. 6 7 8}$ \\
\hline
\end{tabular}

a. Variable(s) entered on step 1: ACHANGE, OSHIP, LEV, ROA, BDOUT, REC, AUDCHANGE, DICHANGE, CEOPIC. Sumber: Hasil olahan SPSS 25.0

Berdasarkan Tabel 4.8, persamaan regresi logistic dalam penelitian ini adalah:

$$
\begin{aligned}
F F R= & -0,388+6,234 \text { ACHANGE }-0,228 \text { OSHIP }-0,173 \text { LEV }+1,299 \text { ROA }-0,66 \text { BDOUT } \\
& +9,635 \text { REC }-0,279 \text { AUDCHANGE }+0.071 \text { DICHANGE }-0,040 \text { CEOPIC }+\varepsilon
\end{aligned}
$$

\section{Financial stability}

Tabel 4.8 menunjukkan koefisien financial stability (ACHANGE) sebesar 6,234 dan nilai signifikansi sebesar 0,000. Ini berarti, hipotesis pertama diterima karena nilai signifikansi yang diperoleh $(0,000)<$ nilai signifikansi yang ditetapkan $(0,05)$. Dapat disimpulkan bahwa financial stability berpengaruh terhadap fraudulent financial reporting. Artinya, setiap pertambahan 1 (satu) pada rasio perubahaan aset akan meningkatkan kemungkinan terjadinya kecurangan sebesar 509,801 .

Perusahaan dengan total aset yang rendah berupaya melakukan kecurangan untuk menarik investor melakukan investasi di perusahaannya. Perusahaan yang memiliki total aset yang rendah pada masa lalu termotivasi untuk meningkatkan jumlah total aset mereka. Namun, dalam upaya mencapai target tersebut, perusahaan terkadang memberikan tekanan pada manajemen sehingga manajemen akan melakukan kecurangan atas laporan keuangan yang menunjukkan hasil peningkatan total aset secara signifikan.

Hasil penelitian ini mendukung hasil penelitian Tiffani \& Marfuah (2015) atas perusahaan manufaktur yang terdaftar di BEI periode 2011-2013; hasil penelitian Beneish (1999) atas perusahaan manufaktur yang terdaftar di BEI periode 2013-2015; dan hasil penelitian Mardianto., (2019) atas perusahaan nonkeuangan yang terdaftar di BEI periode 2011-2016. Namun hasil penelitian Nugraheni \& Triatmoko (2017) atas perusahaan perbankan yang terdaftar di BEI periode 2014-2016 menunjukkan hasil sebaliknya.

\section{Personal financial needs}

Tabel 4.10 menunjukkan koefisien personal financial needs (OSHIP) sebesar -0,228 dan nilai signifikansi sebesar 0,812 . Ini berarti, hipotesis kedua diterima karena nilai signifikansi yang diperoleh $(0,812)>$ nilai signifikansi yang ditetapkan $(0,05)$. Dapat disimpulkan bahwa personal financial needs tidak berpengaruh terhadap fraudulent financial reporting. Kepemilikan manajer yang tinggi atas perusahaan akan membuat manajer lebih berhati-hati dalam menyajikan laporan keuangan demi keberlangsungan perusahaan. Dengan begitu, jumlah kepemilikan saham yang lebih tinggi justru membuat manajemen lebih berfokus untuk meningkatkan kinerja perusahaannya ketimbang melakukan kecurangan.

Hasil penelitian ini sejalan dengan hasil penelitian yang dilakukan oleh Tiffani \& Marfuah (2015) atas perusahaan manufaktur yang terdaftar di BEI periode 2011-2013. Namun, penelitian 
yang dilakukan oleh Nugraheni \& Triatmoko (2017) atas perusahaan perbankan yang terdaftar di BEI periode 2014-2016 menunjukkan hasil yang sebaliknya.

\section{External pressure}

Tabel 4.10 menunjukkan koefisien external pressure (LEV) sebesar -0,173 dan nilai signifikansi sebesar 0,716. Ini berarti, hipotesis ketiga diterima karena nilai signifikansi yang diperoleh $(0,716)>$ nilai signifikansi yang ditetapkan $(0,05)$. Dapat disimpulkan bahwa external pressure tidak berpengaruh terhadap fraudulent financial reporting. Hal ini terjadi karena sampel dalam penelitian ini merupakan perusahaan besar yang dipercaya mampu menyelesaikan kewajiban yang ada. Di samping itu, perusahaan yang memiliki utang dalam jumlah tertentu, dapat melunasi utangnya tersebut.

Hasil penelitian ini sejalan dengan hasil penelitian Mardianto (2019) yang menunjukkan bahwa external pressure tidak berpengaruh terhadap fraudulent financial reporting. Penelitian yang dilakukan oleh Nurbaiti \& Hanafi (2017) juga menunjukkan hasil yang sama. Namun, penelitian yang dilakukan oleh Pamungkas (2018) atas ASEAN Corporate Gorvernance Scorecard (ACGS) menunjukkan hasil yang berbeda, yaitu external pressure berpengaruh terhadap fraudulent financial reporting.

\section{Financial targets}

Tabel 4.10 menunjukkan koefisien financial targets (ROA) sebesar 1,299 dan nilai signifikansi sebesar 0,529. Ini berarti, hipotesis keempat diterima karena nilai signifikansi yang diperoleh $(0,529)>$ nilai signifikansi yang ditetapkan $(0,05)$. Dapat disimpulkan bahwa financial targets tidak berpengaruh terhadap fraudulent financial reporting. Besar kecilnya target ROA yang ingin dicapai tidak memengaruhi manajer untuk melakukan kecurangan. Manajer menganggap target ROA tidak sulit untuk dicapai. Selain itu, keberadaan sistem yang memperbolehkan karyawan dan manajemen memiliki saham dari perusahaan mereka sehingga mereka menjadi pemilik saham sekaligus karyawan perusahaan tersebut, membuat mereka merasa harus berpartisipasi dalam rangka menjaga target keuangan perusahaan.

Hasil Penelitian ini sejalan dengan hasil penelitian yang dilakukan oleh Aprilia (2017) atas perusahaan manufaktur yang terdaftar di BEI periode 2013-2015, sedangkan penelitian oleh Vivianita \& Indudewi (2018) atas perusahaan tambang periode 2014-2016 menunjukkan hasil yang berbeda.

\section{Ineffective monitoring}

Tabel 4.10 menunjukkan koefisien ineffective monitoring (BDOUT) sebesar -0,66 dan nilai signifikansi sebesar 0,582. Ini berarti, hipotesis kelima diterima karena nilai signifikansi yang diperoleh $(0,582)>$ nilai signifikansi yang ditetapkan $(0,05)$. Dapat disimpulkan bahwa nature of industry tidak berpengaruh terhadap fraudulent financial reporting. Dewan komisaris independen diangkat cenderung untuk menghasilkan good corporate governance (GCG) dengan tujuan agar dapat mencegah terjadinya kesalahan penyajian atas laporan keuangan. Pengangkatan dewan komisaris independen bukan hanya dilakukan dengan tujuan tersebut, tapi juga untuk memenuhi regulasi yang ada. Selain itu, mayoritas pemegang saham cenderung lebih memerhatikan kinerja dewan direksi perusahaan sehingga dewan komisaris independen tidak akurat dijadikan sebagai indikator untuk meningkatkan pengaruh melakukan kecurangan. 
Hasil penelitian ini didukung oleh penelitian Mardianto (2019) yang melakukan penelitian atas perusahaan nonkeuangan yang terdaftar di BEI periode 2011-2016; Aprilia (2017) yang melakukan penelitian atas perusahaan manufaktur yang terdaftar di BEI periode 2013-2015. Namun, Tiffani \& Marfuah (2015) atas perusahaan manufaktur yang terdaftar di BEI periode 2011-2013 menunjukkan hasil sebaliknya.

\section{Nature of industry}

Tabel 4.10 menunjukkan koefisien nature of industry (REC) sebesar 9,635 dan nilai signifikansi sebesar 0,000 . Ini berarti, hipotesis keenam diterima karena nilai signifikansi yang diperoleh $(0,000)<$ nilai signifikansi yang ditetapkan $(0,05)$. Dapat disimpulkan bahwa nature of industry berpengaruh terhadap fraudulent financial reporting. Setiap pertambahan 1 (satu) pada selisih rasio perputaran piutang (receivable turnover) akan meningkatkan kemungkinan terjadinya kecurangan atas laporan keuangan sebesar 15.293,071. Adanya penilaian subjektif pada perkiraan piutang tak tertagih menciptakan peluang bagi manajemen untuk melakukan tindakan kecurangan atas akun tersebut. Hal ini dapat dilakukan dengan cara mengurangi penyisihan piutang tak tertagih, meskipun dalam kenyataanya penagihan saldo piutang dalam jumlah besar sulit dilakukan.

Hasil Penelitian ini didukung oleh Pamungkas (2018) yang melakukan penelitian atas ASEAN Corporate Gorvernance Scorecard (ACGS) periode 2012-2016. Hasil penelitian ini juga didukung oleh Nurbaiti \& Hanafi (2017) yang melakukan penelitian atas perusahaan property dan realestate yang terdaftar di BEI periode 2013-2017. Namun, hasil penelitian ini tidak didukung oleh Vivianita \& Indudewi (2018) yang melakukan penelitian atas perusahaan tambang yang terdaftar di BEI periode 2014-2016; Tiffani \& Marfuah (2015) yang melakukan penelitian atas perusahaan manufaktur yang terdaftar di BEI periode 2011-2013.

\section{Auditor change}

Tabel 4.10 menunjukkan koefisien auditor change (AUDCHANGE) sebesar -0,279 dan nilai signifikansi sebesar 0,372 . Ini berarti, hipotesis ketujuh diterima karena nilai signifikansi yang diperoleh $(0,372)>$ nilai signifikansi yang ditetapkan $(0,05)$. Dapat disimpulkan bahwa auditor change tidak berpengaruh terhadap fraudulent financial reporting. Perusahaan mengganti auditor karena tidak puas dengan hasil kerja yang dilakukan pada periode sebelumnya. Selain itu, penetapan auditor juga dilakukan dalam RUPS sehingga lebih banyak dipengaruhi oleh keputusan para pemegang saham. Perusahaan cenderung memiliki motivasi yang baik dengan menggunakan independent auditor dan secara objektif melakukan audit demi meningkatkan kinerja perusahaan di masa depan. Akan tetapi, jika perusahaan mulai tidak puas dengan kinerja auditor yang tidak dapat dipengaruhi atau diganggu oleh perusahaan untuk melakukan manipulasi hasil audit, maka kecurangan cenderung lebih tinggi.

Hasil penelitian ini diperkuat oleh Vivianita \& Indudewi (2018) yang melakukan penelitian atas perusahaan tambang yang terdaftar di BEI tahun 2014-2016 serta penelitian Aprilia (2017) atas perusahaan manufaktur yang terdaftar di BEI tahun 2013-2015. Namun, penelitian Mardianto (2019) atas perusahaan nonkeuangan yang terdaftar di BEI tahun 2011-2016 menunjukkan hasil yang sebaliknya. 


\section{Director change}

Tabel 4.10 menunjukkan koefisien director change (DICHANGE) sebesar 0,071 dan nilai signifikansi sebesar 0,802. Ini berarti, hipotesis kedelapan diterima karena nilai signifikansi yang diperoleh $(0,802)>$ nilai signifikansi yang ditetapkan $(0,05)$. Dapat disimpulkan bahwa director change tidak berpengaruh terhadap fraudulent financial reporting. Pergantian dewan direksi di dalam perusahaan yang dideskripsikan dalam laporan tahunan, dapat terjadi karena hasil dari RUPS. Pergantian yang ditetapkan oleh perusahaan dengan harapan meningkatkan kinerja perusahaan yang lebih baik dari periode sebelumnya. Pemilik saham juga cenderung ingin meningkatkan kinerja perusahaan dengan menetapkan dewan direksi yang lebih kompeten.

Hasil Penelitian ini sejalan dengan Nurbaiti \& Hanafi (2017) yang melakukan penelitian atas perusahaan property dan realestate yang terdaftar di BEI periode 2013-2017; penelitian Aprilia (2017) atas perusahaan manufaktur yang terdaftar di BEI periode 2013-2015. Namun, Septriani \& Handayani (2018) yang melakukan penelitian atas perusahaan perbankan yang terdaftar di BEI periode 2013-2016 menunjukkan hasil sebaliknya.

\section{Frequent number of CEO's picture}

Tabel 4.10 menunjukkan koefisien frequent number of CEO's picture (CEOPIC) sebesar 0,4 dan nilai signifikansi sebesar 0,432 . Ini berarti, hipotesis kesembilan diterima karena nilai signifikansi yang diperoleh $(0,432)>$ nilai signifikansi yang ditetapkan $(0,05)$. Dapat disimpulkan bahwa frequent number of CEO's picture tidak berpengaruh terhadap fraudulent financial reporting. Jumlah foto $\mathrm{CEO}$ perusahaan yang muncul cenderung hanya untuk memperkenalkan diri bagi pembaca laporan tahunan. Dengan adanya foto yang terpampang dalam laporan tahunan tentunya seorang CEO akan mempertahankan harga dirinya dengan tidak melakukan kecurangan. Selain itu, frekuensi kemunculan foto CEO yang besar juga dipengaruhi oleh jumlah dewan direksi perusahaan tersebut, sehingga freukuensi kemunculan foto CEO tidak dapat dijadikan sebagai indkator pengaruh terjadinya kecurangan.

Hasil penelitian ini didukung oleh Nugraheni \& Triatmoko (2017) yang melakukan penelitian atas Badan Usaha Milik Negara (BUMN) yang terdaftar di BEI periode 2013-2017. Namun, penelitian yang dilakukan oleh Aprilia (2017) atas perusahaan manufaktur yang terdaftar di BEI tahun 2013-2015, serta Vivianita \& Indudewi (2018) yang melakukan penelitian terhadap perusahaan tambang yang terdaftar di BEI periode 2014-2016, menunjukkan hasil sebaliknya.

\section{KESIMPULAN \& SARAN \\ 5.1.Kesimpulan}

Hasil pengujian analisis regresi logistik selama tiga tahun pengamatan (2015-2017) menunjukkan bahwa secara statistik terbukti terdapat pengaruh signifikan financial stability terhadap fraudulent financial reporting; secara statistik tidak terbukti terdapat pengaruh signifikan personal financial needs terhadap fraudulent financial reporting; secara statistik tidak terbukti terdapat pengaruh signifikan external pressure terhadap fraudulent financial reporting; secara statistik tidak terbukti terdapat pengaruh signifikan financial targets terhadap fraudulent financial reporting; secara statistik tidak terbukti terdapat pengaruh signifikan ineffective monitoring terhadap fraudulent financial reporting; secara statistik tidak terbukti terdapat pengaruh signifikan nature of industry terhadap fraudulent financial reporting; secara statistik tidak terbukti terdapat 
pengaruh signifikan auditor change terhadap fraudulent financial reporting; secara statistik tidak terbukti terdapat pengaruh signifikan director change terhadap fraudulent financial reporting; secara statistik tidak terbukti terdapat pengaruh signifikan frequent number of CEO's picture terhadap fraudulent financial reporting.

\subsection{Saran Untuk Penelitian Selanjutnya}

Penelitian selanjutnya dapat menggunakan alat ukur lain untuk mengukur fraudulent financial reporting, seperti discretionaly accruals (DACC), F-Score Model, dan alat ukur lainnya agar hasil penelitian menjadi lebih signifikan.

Penelitian selanjutnya dapat mengombinasikan metode kuantitatif dan kualitatif dalam metode penelitiannya. Beberapa elemen dalam fraud pentagon masih sulit untuk diukur apabila hanya menggunakan metode kuantitatif saja.

\section{REFERENSI}

ACFE. (2014). Report To The Nation on Occupational Fraud and Abuse 2014 Global Fraud Study. Association Of Certified Fraud Examiners, pp. 1-80.

AICPA. (2002). AU Section 316 : Consideration of Fraud in a Financial Statement Audit. pp. 1719-1770.

Alfa Vivianita., Dian Indudewi. (2018). Financial Statement Fraud Pada Perusahaan Pertambangan Yang Dipengaruhi Oleh Fraud Pentagon Theory (Studi Kasus Di Perusahaan Tambang Yang Terdaftar Di Bei Tahun 2014-2016). Jurnal Dinamika Sosial Budaya, 20(1), 1-15.

Aprilia. (2017). Analisis Pengaruh Fraud Pentagon Terhadap Kecurangan atas laporan keuangan Menggunakan Beneish Model Pada Perusahaan Yang Menerapkan Asean Corporate Governance Scorecard. Jurnal Aset (Akuntansi Riset), 9(1), 101-132.

Beneish, D. (1999). The Detection Of Earning Manipulation. Financial Analyts Journal, 55(5), 24-36.

Beneish, M. D. (November/December 1999). The Detection of Earnings Manipulation. Financial Analysts Journal, 24-36.

Christopher J, Skousen., Kevin R, Smith., Charlotte J, Wright. (2009). Detecting and Predicting Financial Statement Fraud. The Effectiveness of The Fraud Triangle and SAS No. 99. Advances in Financial Economics.

Cressey, D. (1953). Other People's Money; a Study in the Social Psychology of Embezzlement. Glencoe. IL: Free Press.

David, T, Wolfe., Dana, R, Hermanson. (2004). The Fraud diamond : Considering The Four Element of Fraud. CPA Journal, 74(12), 38-42.

Examiners, A. o. (2016). Report to Nation. https://www.acfe.com/rttn2016/docs/2016-report-tothe-nations.pdf.

Horwarth, C. (2011 b). Why the fraud triangle is no longer enough. https://www.crowe.com.

Horwarth, C. (2012). The Mind Behind The Fraudsters Crime :Key Behavioral and Environmental Element. 
Imam, G. (2013). Aplikasi Analisis Multivariat Dengan Program IBM SPSS 20. Semarang: Badan Penerbit Universitas Diponegoro.

Indonesia, I. A. (2018). Standar Akuntansi Keuangan. Retrieved September 2019, from IAI global: http://iaiglobal.or.id/v03/standar-akuntansi-keuangan/sak-efektif-15-sak-efektif-per-1januari-2018.

Jensen, C, Meckling, H. (1976). Theory of the firm: Managerial behavior, agency costs and ownership structure. Journal of Financial Economics, 305-360.

Laila Tiffani., Marfuah. (2015). Deteksi Financial Statement Fraud dengan Analisis Fraud Triangle pada Perusahaan Manufaktur yang terdaftar di Bursa Efek Indonesia. JAAI, 19(2), 112125.

Mardianto., Tiono, C. (2019). Analisis Pengaruh Fraud Triangle Dalam Mendeteksi Kecurangan atas laporan keuangan. Jurnal Benefita, 87-103.

Nugraheni, K., Triatmoko, H. (2017). Analisis Faktor- Faktor yang Memengaruhi Terjadinya Financial Statement Fraud: Prespektif DIamond Fraud Theory. Jurnal Akuntansi dan Auditing, 14(2), 118-143.

Pamungkas, D., Utomo, D. (2018). Fraudulent financial reporting: An Application of Fraud Pentagon Theory to Association of Southeast Asian Nations Corporate Governance Scorecard. Journal of Advanced Research in Law and Economics, 1729-1737.

Tuanakotta, M. (2013 a). Audit Berbasis ISA (International Standards on Auditing). Jakarta: Salemba Empat.

Tuanakotta, M. (2013). Mendeteksi Manipulasi Laporan Keuangan. jakarta: Salemba Empat. Jakarta: Salemba Empat.

Wolfe, T \& Hermanson, R. (2004). The Fraud diamond : Considering The Four Element of Fraud. The CPA Journal, 38-42.

Yossi, Septriani., Desi Handayani. (2018). Mendeteksi Kecurangan Laporan Keuangan dengan Analisis Fraud Pentagon. Jurnal Akuntansi, Keuangan dan Bisnis, 11(1), 11-23.

Zulvi Nurbaiti., Rustam Hanafi. (2 Juli 2017). Analisis Pengaruh Fraud diamond Dalam Mendeteksi Tingkat Accounting Irregularities. Jurnal Akuntansi Indonesia, 6(2), 167-184. 